\title{
Prevalence of Cryptosporidium SPP. (EUCOCCIDIORIDA: CRYPTOSPORIIDAE) IN SEVEN SPECIES OF FARM ANIMALS IN TUNISIA
}

\author{
SOLTANE R.*, GUYOT K.**, DEI-CAS E.** \& AYADI A.*
}

\section{Summary :}

1,001 faecal samples were obtained from 89 sheep llambs and adult), 184 goats, 190 horses, 178 rabbits, 110 camels,

200 broiler chicken and 50 turkeys housed in farms from different localities in Tunisia. All samples were analysed for

Cryptosporidium oocysts by microscopic examination of smears stained by modified Ziehl Neelsen technique. The parasite was detected in ten lambs and adult sheep (1 $1.2 \%)$ and nine broiler chicken (4.5\%). Molecular characterization, performed in four animals, identified C. bovis in three lambs and C. meleagridis in one broiler chicken. This work is the first report on

Cryptosporidium in farm animals in Tunisia.

KEY WORDS : Cryptosporidium, Apicomplexa, farm animals, prevalence, genotyping, Tunisia.

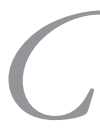

Tryptosporidium (Apicomplexa: Eucoccidiorida: Cryptosporiidae) is a ubiquitous enteropathogen and has been reported from many geographical regions of the world. The parasite is recognized as one of the most common causes of diarrhoea in humans and farm animals (Caccio, 2005; de Graaf et al., 1999; Joachim, 2004). Cryptosporidial infection of livestock may have an important economic impact on farmers because of high morbidity and sometimes high mortality rates among animals (Sunnotel et al., 2006). Despite its wide distribution and obvious relevance to animal health, no data are available about the Cryptosporidium prevalence in animals in Tunisia. The present study was undertaken to assess the relevance of Cryptosporidium in poultry and mammals in Tunisian farms in different geographical locations.

\footnotetext{
* Laboratoire de Parasitologie-Mycologie, Faculté de Médecine, Sfax, Tunisie.

* Institut Pasteur de Lille, Laboratoire Écologie du Parasitisme (EA3609, IFR142) et Service de Parasitologie-Mycologie, Département de Microbiologie, Faculté de Médecine, Centre Hospitalier Régional Universitaire, Lille, France.

Correspondence: Raya Soltane.

Tel. : 0021621248198 - Fax : 0021671399789.

E-mail: soltane_raya@yahoo.fr
}

Résumé : Prévalence de CRYPTOSPORIDIUM SPP. (EuCOCCIDIORIDA : CRYPTOSPORIIDAE) CHEZ SEPT ESPÈces D'ANIMAuX De Ferme EN Tunisie 1001 prélèvements fécaux ont été obtenus à partir de 89 moutons, 184 chèvres, 190 chevaux, 178 lapins, 110 chameaux, 200 poulets et 50 dindes élevés dans des fermes de différentes localités en Tunisie. Tous les prélèvements ont été analysés pour la recherche de Cryptosporidium par examen microscopique des frottis colorés au Ziehl Neelsen modifié. Le parasite a été détecté chez dix ovins (17,2\%) et neuf poulets (4,5\%). La caractérisation moléculaire réalisée pour quatre isolats a identifié $\mathrm{C}$. bovis chez trois agneaux et $\mathrm{C}$. meleagridis chez un poulet. Ce travail est le premier rapport sur Cryptosporidium chez des animaux de ferme en Tunisie.

MOTS CLÉS : Cryptosporidium, Apicomplexa, animaux de ferme, prévalence, génotypage, Tunisie.

\section{MATERIAL AND METHODS}

\section{FAECAL SPECIMENS AND SAMPLE SITES}

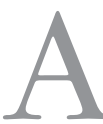
total of 1,001 faecal specimens was collected in 2003 and 2004 from animals located in priva1 tely owned farms or State farms located in different provinces of Tunisia (Table I, Fig. 1). 89 were collected from ovine (30 lambs and 59 adults) housed in three different farms (Fig. 1). Other faecal specimens were sampled from 184 goats, 190 horses, 178 rabbits, 110 camels, 200 broiler chickens and 50 turkeys (Table I, Fig. 1). All these samples were stored at $4^{\circ} \mathrm{C}$ in a $2.5 \%$ aqueous potassium dichromate solution until examination.

\section{MICROSCOPIC EXAMINATION AND MOLECULAR ANALYSIS FOR GENOTYPING}

For the detection of Cryptosporidium by microscopy, we proceeded as previously described in another of our work also published in this issue (Soltane et al., 2007). Parasite genotyping could have been done only for four isolates including three from lambs and one from broiler chicken. DNA extraction and PCR at $18 \mathrm{~S}$ rDNA and Laxer loci were performed as described in Soltane et al. (2007). The nucleotide sequences gene- 


\begin{tabular}{|c|c|c|c|}
\hline Animals (age) & $\begin{array}{c}\text { Farm } \\
\begin{array}{c}\text { number-geographical } \\
\text { location }\end{array}\end{array}$ & $\begin{array}{c}\text { No. of } \\
\text { examined animals }\end{array}$ & $\begin{array}{c}\text { No. of positive } \\
\text { for Cryptosporidium } \\
(\%)\end{array}$ \\
\hline Lambs ( $<3$ months) & 2 - Tunis * & 30 & $5(16.7 \%)$ \\
\hline Sheep (> 1 year) & $\begin{array}{l}2 \text { - Tunis } \\
3 \text { - Sidi Bouzid } \\
4 \text { - Médenine } \\
\quad \text { Total }\end{array}$ & $\begin{array}{r}4 \\
25 \\
30 \\
59\end{array}$ & $\begin{array}{c}0 \\
3(12 \%) \\
2(6.7 \%) \\
5(8.5 \%)\end{array}$ \\
\hline Goat (1-7 years) & $\begin{array}{l}5 \text { - Tataouine } \\
6 \text { - Médenine } \\
7 \text { - Le Kef } \\
8 \text { - Siliana } \\
9 \text { - Tataouine }\end{array}$ & $\begin{array}{l}40 \\
35 \\
30 \\
25 \\
54 \\
\end{array}$ & $\begin{array}{l}0 \\
0 \\
0 \\
0 \\
0\end{array}$ \\
\hline Horse (1-3 years) & $\begin{array}{l}10 \text { - Tunis } \\
11 \text { - Nabeul } \\
12 \text { - Kairouan } \\
13 \text { - Kairouan } \\
14 \text { - Nabeul }\end{array}$ & $\begin{array}{l}50 \\
35 \\
25 \\
30 \\
50\end{array}$ & $\begin{array}{l}0 \\
0 \\
0 \\
0 \\
0\end{array}$ \\
\hline Rabbit (1-2 months) & 15 - Tunis & 178 & 0 \\
\hline Camel (3-8 months) & 16 - Ben Guerdan & 110 & 0 \\
\hline Broiler chicken (0-56 days) & $\begin{array}{l}17 \text { - Tunis } \\
18 \text { - Le Kef* } \\
\quad \text { Total }\end{array}$ & $\begin{array}{r}90 \\
110 \\
200\end{array}$ & $\begin{array}{l}3(3.3 \%) \\
6(5.5 \%) \\
9(4.5 \%)\end{array}$ \\
\hline Turkey & 19 - Siliana & 50 & 0 \\
\hline
\end{tabular}

* Farms from witch the samples for genotyping were derived.

Table I. - Prevalence of Cryptosporidium in farm animals.

rated in this study have been deposited in GenBank under accession numbers EF158460 to EF158461.

\section{RESULTS}

A total of 1,001 faecal specimens were collected from 89 ovine, 184 goats, 190 horses, 178 rabbits, 110 camels, 200 broiler chickens and 50 turkeys housed in 18 farms in different localities in Tunisia from 2003 to 2004 (Fig. 1). Cryptosporidium was found in lambs or adult sheep from all three included farms (Table I), with an overall prevalence of $11.2 \%$. Lambs were found more often infected ( 5 out of 30, $16.7 \%$ ) than adult sheep ( 5 out of $59,8.5 \%$ ) but the difference was not statistically significant. Diarrhoea was not present in any of these animals. In chicken, Cryptosporidium was only identified in broiler chicken aged up to 56 days with a prevalence of $4.5 \%$ (Table I). Chicken seem to be more susceptible to infection at the age of 22 to 28 days. In this study, Cryptosporidium was not found in horses, rabbits, camels, and turkeys.

The molecular-based analysis concerned four Cryptosporidium isolates: three from lambs and one from chicken. DNA was amplified by nested PCR and the resulting fragment of the 18s rRNA gene was sequenced. Sequences obtained from the three lamb-derived isolates were $100 \%$ homologous to each other. A Blast analysis in the GenBank database did not find any

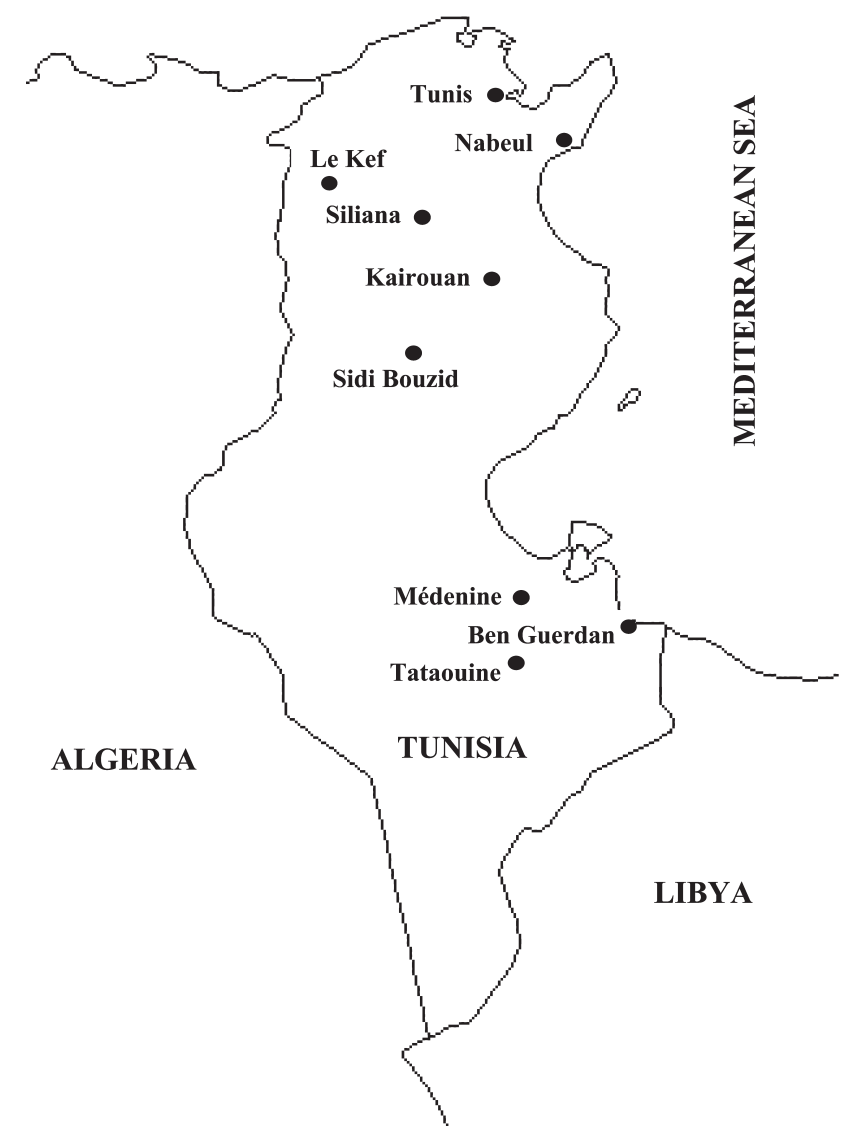

Fig. 1. - Map of Tunisia showing the geographical location of the different farms from where sampled animals were originated. 
exact match with an existing sequence but clustered these sequences with the $C$. bovis sequence (identity of $99.5 \%$ with EF514234). The sequence of the chickenderived isolate was identified as $C$. meleagridis. The Cryptosporidium DNA diagnostic fragment characterized by Laxer et al (Guyot et al., 2002; Laxer et al., 1991) was amplified by PCR for the broiler chickenderived isolate only. In agreement with the genotyping of the $18 \mathrm{~S}$ rRNA gene, C. meleagridis was identified by RFLP (data not shown). The three Cryptosporidium DNA samples from lamb-derived isolates (identified as C. bovis at the $18 \mathrm{~S}$ rRNA gene) failed to be amplified at this same locus, in spite of repeated attempts.

\section{DISCUSSION}

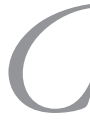

Typtosporidium infections in sheep and poultry have been reported in many countries throughout the world. The results that we report in the present work have shown that Cryptosporidium infection occurred also in these animals in Tunisia. This study with that one we concomitantly published in this issue (Soltane et al., 2007) are thus the first reports about Cryptosporidium prevalence in different farm animals in a country of North Africa. In the present study, Cryptosporidium was identified in ovine with a prevalence of $16.7 \%$ in lambs and $8.5 \%$ in adult sheep. None of these Cryptosporidium-infected animal showed disease symptoms. This is coherent with the fact that C. bovis was identified in three lambs (Table I). Indeed, C. bovis, a species recently described (Fayer et al., 2005), is reported to be not associated with signs of disease (Santin et al., 2004). C. bovis has been reported as preferentially infect post-weaned calves (> 3 months of age) but has been also found in sheep (Fayer et al., 2006; Santin et al., 2007). Very recently, Santin et al. (2007) identified also C. bovis in lambs. This study has shown that the molecular diagnostic tool based on the Laxer sequence, that is already known to failed in the detection of C.felis, C. canis, C. suis and C. muris (Jiang $\&$ Xiao, 2003), also failed to amplify C. bovis. The variability in the primer sequences is the probable explanation for the failure in amplifying DNA.

Though, in different regions of the world, Cryptosporidium infections have been reported in goats, rabbits (Marlier et al., 2003; Peeters, 1988; Shiibashi et al., 2006), horses (Browning et al., 1991; Darabus et al., 2001; Grinberg et al., 2003; Majewska et al., 1999; Majewsk et al., 2004; Olson et al., 1997), all examined animals in these species in Tunisia were not found to be infected with Cryptosporidium. The age of sampled animals as well as animal management practices or environmental conditions could explain such results.

The present work is the first report on Cryptosporidium occurrence in different host species in Tunisia asso- ciating molecular characterization of few parasite isolates. However, more comprehensive epidemiological studies are needed to elucidate accurately the circulation of Cryptosporidium in farms in this country. Moreover, further subtyping of parasite isolates using highly polymorphic markers will be very useful for the study of the worldwide distribution of Cryptosporidium species subtypes in livestock (Feng et al., 2007; Thompson et al., 2007; Trotz-Williams et al., 2006; Xiao et al., 2007).

\section{ACKNOWLEDGEMENTS}

he authors thank Nausicaa Gantois from Pasteur Institute of Lille for technical assistance in sequencing.

\section{REFERENCES}

Browning G.F., Chalmers R.M., Snodgrass D.R., Batt R.M., Hart C.A., Ormarod S.E., Leadon D., Stoneham S.J \& RossDALE P.D. The prevalence of enteric pathogens in diarrhoeic thoroughbred foals in Britain and Ireland. Equine Veterinary Journal, 1991, 23, 405-409.

Caccio S.M. Molecular epidemiology of human cryptosporidiosis. Parassitologia, 2005, 47, 185-192.

Darabus G.H., Cosoroaba I., Oprescu I \& Morariu S.M. Épidémiologie de la cryptosporidiose chez les animaux dans l'Ouest de la Roumanie. Revue de Médecine Vétérinaire, 2001, 152, 399-404.

de Graaf D.C., Vanopdenbosch E., Ortega-Mora L.M., AbBassi H \& PeEters J.E. A review of the importance of cryptosporidiosis in farm animals. International Journal for Parasitology, 1999, 29, 1269-1287.

FAYer R., SAntin M \& XiaO L. Cryptosporidium bovis n. sp. (Apicomplexa: Cryptosporidiidae) in cattle (Bos taurus). Journal of Parasitology, 2005, 91, 624-629.

Fayer R., Santin M., Trout J.M \& Greiner E. Prevalence of species and genotypes of Cryptosporidium found in 1-2year-old dairy cattle in the eastern United States. Veterinary Parasitology, 2006, 135, 105-112.

Feng Y., Ortega Y., He G., Das P., Xu M., Zhang X., Fayer R., GateI W., CAMA V \& XIAO L. Wide geographic distribution of Cryptosporidium bovis and the deer-like genotype in bovines. Veterinary Parasitology, 2007, 144, 1-9.

Grinberg A., Oliver L., Learmonth J.J., Leyland M., Roe W \& PomRoY W.E. Identification of Cryptosporidium parvum 'cattle' genotype from a severe outbreak of neonatal foal diarrhoea. Veterinary Record, 2003, 153, 628-631.

Guyot K., Follet-Dumoulin A., Recourt C., Lelievre E., Cailliez J.C \& DEI-CAS E. PCR-restriction fragment length polymorphism analysis of a diagnostic 452-base-pair DNA fragment discriminates between Cryptosporidium parvum and C. meleagridis and between C. parvum isolates of human and animal origin. Applied and Environmental Microbiolology, 2002, 68, 2071-2076. 
JIANG J \& XIAO L. An evaluation of molecular diagnostic tools for the detection and differentiation of human-pathogenic Cryptosporidium spp. Journal of Eukaryotic Microbiology, 2003, 50 (Suppl.), 542-547.

JOACHIM A. Human cryptosporidiosis: an update with special emphasis on the situation in Europe. Journal of Veterinary Medicine. B, Infectious Diseases and Veterinary Public Health, 2004, 51, 251-259.

LaXer M.A., Timblin B.K \& Patel R.J. DNA sequences for the specific detection of Cryptosporidium parvum by the polymerase chain reaction. American Journal of Tropical Medicine and Hygiene, 1991, 45, 688-694.

Majewska A.C., Werner A., Sulima P \& Luty T. Survey on equine cryptosporidiosis in Poland and the possibility of zoonotic transmission. Annals of Agricultural and Environmental Medicine, 1999, 6, 161-165.

Majewska A.C., SolarczyK P., Tamang L \& Graczyk T.K. Equine Cryptosporidium parvum infections in western Poland. Parasitology Research, 2004, 93, 274-278.

Marlier D., Dewree R., Delleur V., Licois D., Lassence C., PouLipoulis A \& VindeVogel H. Description des principales étiologies des maladies digestives chez le lapin européen (Oryctolagus cuniculus). Annales de Médecine Vétérinaire, 2003, 147, 385-392.

Olson M.E., Thorlakson C.L., Deseluers L., Morck D.W \& MCAllister T.A. Giardia and Cryptosporidium in Canadian farm animals. Veterinary Parasitology, 1997, 68, 375-381.

PEETERS J.E. Recent advances in intestinal pathology of rabbits and further perspectives. $4^{\text {th }}$ Congress of the World Rabbit Sciences Association, Budapest, Hungary, 1988, 293-313.

Santin M., Trout J.M., Xiao L., Zhou L., Greiner E \& Fayer R. Prevalence and age-related variation of Cryptosporidium species and genotypes in dairy calves. Veterinary Parasitology, 2004, 122, 103-117.

SAntin M., Trout J.M. \& FAyer R. Prevalence and molecular characterization of Cryptosporidium and Giardia species and genotypes in sheep in Maryland. Veterinary Parasitology, 2007, 146, 17-24.

Shimbashi T., Imai T., Sato Y., Abe N., Yukawa M \& Nogami S. Cryptosporidium infection in juvenile pet rabbits. Journal of Veterinary Medical Science, 2006, 68, 281-282.

Soltane R., Guyot K., Dei-Cas E. \& Ayadi A. Cryptosporidium parvum (Eucoccidiorida: Cryptosporiidae) in calves: results of a longitudinal study in a dairy farm in Sfax, Tunisia. Parasite, 2007, 14 (4), 309-312.

Sunnotel O., Lowery C.J., Moore J.E., Dooley J.S.G., XiaO L. \& Millar B.C. Cryptosporidium. Letters in Applied Microbiolgy, 2006, 43, 7-16.

Thompson H.P., DoOley J.S., Kenny J., McCoy M., Lowery C.J., MOORE J.E \& XIAO L. Genotypes and subtypes of Cryptosporidium spp. in neonatal calves in Northern Ireland. Parasitology Research, 2007, 100 (3), 619-624.

Trotz-Williams L.A., Martin D.S., Gatei W., Cama V., Peregrine A.S., Martin S.W., Nydam D.V., Jamieson F \& XiaO L. Genotype and subtype analyses of Cryptosporidium isolates from dairy calves and humans in Ontario. Parasitology Research, 2006, 99, 346-352.
Xiao L., Zhou L., Santin M., Yang W \& Fayer R. Distribution of Cryptosporidium parvum subtypes in calves in eastern United States. Parasitology Research, 2007, 100 (4), 701-706.

Reçu le 3 février 2007 Accepté le 17 juillet 2007 